\title{
"A Mestra dos Costumes": Uma Opinião sobre Música do Acadêmico José Bonifácio de Andrada
}

\author{
Diósnio Machado Neto
}

\section{José Bonifácio, Senhor de um Universo de Luzes}

A importância da personalidade de José Bonifácio de Andrada e Silva para a história política do Brasil tem produzido inúmeros textos tratando dos mais variados aspectos da sua vida e obra. Muitos autores dedicados ao trabalho de compreender a dimensão do ilustre santista elaboraram completas biografias, ao longo das quais a proeminência dos sucessos de 1822, não sem razão, acabava por se constituir nos alicerce de suas obras. Estas incluem aspectos de sua formação juvenil, junto ao $3^{\circ}$ Bispo de São Paulo, Dom Frei Manuel da Ressurreição, um iluminista franciscano; de suas viagens pelo Brasil, da formação européia, da atuação na Academia Real de Ciências, da participação na burocracia imperial na Metrópole e finalmente da sua atuação na vida política brasileira.

A dificuldade de se escrever sobre José Bonifácio reside justamente em sua erudição; disserta, algumas vezes com predicados de especialista e outras como diletante apaixonado, sobre os mais variados temas, tornando a abordagem sistemática de sua obra uma tarefa árdua, pois multidisciplinar. Mineralogia, literatura e história são algumas das áreas sobre que discorre com muita propriedade. Seus discursos diante da Academia Real de Ciência de Lisboa abrem o caminho para amplas possibilidades de especulação, pois o acadêmico, secretário da referida entidade, enfrentava a tarefa de criticar monografias das mais diversas disciplinas científicas. Exemplar é aquele proferido em 24 de junho de 1815 (Falcão, 1963, p. 353); no qual Andrada faz uma síntese da história da literatura européia, para louvar a importância das corporações literá- 
rias; observa que "o aumento ou decadência das Letras em qualquer nação é o critério mais seguro para ajuizarmos da sua civilização e prosperidade; porque as causas que promovem as Ciências e as Artes, são as mesmas que fomentam e adiantam a felicidade da nação..."; mensagem para o futuro de uma nação que iria ajudar a fundar e que se tornou triste constatação de uma realidade anunciada! Com a mesma facilidade falava sobre as medidas tomadas pelo governo imperial para modificar os sistemas de pesos e medidas, astronomia, ortografia portuguesa, poesia, sobre a necessidade da elaboração de mapas geográficos, pesquisas para se criarem vacinas contra a doença dos "bexiguentos" etc. ${ }^{1}$ Nos seus manuscritos, ainda como ilustração de seu espírito, podemos encontrar assuntos dos mais variados, tendo, porém, especial apreço pela história brasileira. Rica fonte de informações, Bonifácio abre um universo que, depois de 162 anos de sua morte, ainda é desconhecido dos pesquisadores; como exemplo, os comentários sobre Heliodoro Hese, o qual Francisco Martins dos Santos, no seu livro História de Santos (Santos, 1986, p. 370), identifica como Eliodoro Eobano Pereira, que chefiou em 1566, uma expedição para ajudar Estácio de Sá no combate aos franceses no Rio de Janeiro. Palavras de José Bonifácio, comentando sobre o apresamento de Hans Staden, dizia que este estaria na companhia de,

[...] um espanhol, morador em S. Vicente e Heliodoro Hese, filho de Oebano Hese, o qual morava em um engenho na Ilha de São Vicente, que era de José Osório Genova, de quem era caixeiro e contador Heliodoro Hese, tinha ele mandado caçar ao mato seu escravo, e indo a buscá-lo viu-se rodeado de índios inimigos e o aprisionaram, e o levaram para a sua aldeia por mar, que ficava dai a 30 léguas chamada Uvatibi...2.

1. Este ecletismo de José Bonifácio fundamentava-se na própria atuação da Academia Real de Ciências. Instituição criada em 1779, agrupava intelectuais lusos e brasileiros com o objetivo de sistematizarem a crise portuguesa, buscando soluç̃os a partir de uma ótica cientificista (Silva, 1999, pp. 74-75), some-se a própria característica do homem iluminista, que desejava uma aplicação prática do saber teórico, sendo, acima de tudo, um reformador (Silva, 1999, p. 77). Ana Rosa Cloclet da Silva, buscando a formação do pensamento de José Bonifácio, detém-se para uma criteriosa análise dos fundamentos e objetivos da Academia portuguesa; nos mostra como a preocupação com a introdução das luzes era ponto crucial das reformas iniciadas pelo Marquês de Pombal, e de que forma, o brasileiro Andrada era estratégico dentro de uma discussão que buscava saídas para reerguer um Império cada vez mais dependente de sua colônia americana e atrasado em relação as grandes potências econômicas - França e Inglaterra - onde o liberalismo e o iluminismo iam reformando as estruturas estabelecidas (Silva, 1999, pp. 68-83).

2. AMP, coleção José Bonifácio, doc. D-67, I-1-9. 
Sobre o caixeiro Heliodoro, diz: "...que esteve com Staden em São Vicente era filho do grande literato e famoso Oebano Hessio..."3. Assim como o texto citado, um imenso elenco de informações povoam os escritos do "Patriarca", tornando as obras dedicadas a ele, como não poderia deixar de ser, passíveis de lacunas, próprias da dimensão do personagem e as idéias e fatos que gravitam na sua órbita, sendo assim, para fundamentar o tema deste texto, destacaremos três trabalhos de organização dos escritos do mineralogista santista.

Em 1963, uma comissão, patrocinada pelo município de Santos para comemorar os duzentos anos de seu nascimento, tendo como organizador Edgar Cerqueira Falcão, agrupou, em três volumes, vários trabalhos, documentos e comentários que ilustrariam a vida e obra de José Bonifácio. Mais recente é o trabalho da pesquisadora Míriam Dolhnikoff no qual os textos escolhidos demonstram a preocupação do Brasil e esboçam o "projeto" de Bonifácio para o desenvolvimento do país independente. Trata-se do livro Projetos para o Brasil, que traz idéias sobre os mais variados problemas da sociedade brasileira de outrora e as idéias do autor a respeito de como deveria se concretizar o processo de seu desenvolvimento. Reúne também escritos sobre sua relação com o Império e algumas considerações autobiográficas; mostra um homem conhecedor dos problemas do Brasil, monarquista por pressão, constitucional, partidário da abolição da escravatura, da diversificação dos cultivos agrícolas que acompanhariam a melhoria das estradas para o transporte da produção. Faz incisivas radiografias dos brasileiros, que seriam amantes do belo, suportariam o roubo, mas não o vilipêndio, ignorantes por falta de instrução, mas cheios de talento e imaginação, desatenciosos, apaixonados por sexo devido ao clima, à vida e à educação; um povo que empreende muito, porém, termina pouco; são os atenienses da América (Silva, 1998, p. 183); mostram obstinações em puerilidades, são bons para padres, rábulas e escrivães porque são modos de vida que não carecem de trabalho aturado, e de boa conduta...(Silva, 1998, p. 186), ser lavrador, comenta, exigiria deles esforço. Dolhnikoff reúne textos que ilustram bem os problemas e projetos de José Bonifácio para a nação nascente, porém existem outras facetas que escaparam à seleção da pesquisadora e poderiam realçar, ainda mais, as luzes do projeto do iluminista santista, e que

3. Idem, doc. D-64, I-1-11. 
formavam parte, embora camufladas, das idéias do político para o Brasil. Mais de uma vez, nos textos selecionados, refere-se o pensador à importância da música para a educação e formação dos costumes ${ }^{4}$, pondo em questão a proximidade do santista com a arte; lembremos do discurso de 1815 citado acima, e veremos que, mesmo não dissertando largamente sobre a questão, o desenvolvimento das artes e ciências era projeto intrínseco do Andrada político.

$\mathrm{Na}$ comemoração do centenário da independência, Os Andradas, de Alberto Souza, rememora a vida e os fatos que cercaram um dos principais fundadores do império brasileiro. Em três volumes sistematiza a vida, através da vila natal, onde faz um amplo estudo dos moradores e familiares; a formação e atuação em Portugal, os sucessos da independência e atuação política de José Bonifácio e seus irmãos. No terceiro volume seleciona poesias, memórias científicas, representações e, finalizando, abre um capítulo com o subtítulo "Opiniões sobre a Música" (Souza, 1922, vol. 1, pp. 431-432). É de se ressaltar a sensibilidade do pesquisador para um aspecto da vida de uma das mais importantes personalidades do país que nunca suscitou maiores comentários, nem de biógrafos, nem de historiadores ocupados no garimpo dos costumes e idéias de tempos passados!

A abordagem deste tema, a opinião sobre a música vertida por José Bonifácio de Andrada e Silva em 1818, diante da Academia Real de Sciencias de Lisboa, é o problema deste texto. Nele buscaremos esquematizar as influências da música na educação do jovem Bonifácio, sua estada na Europa e o que lá ocorria musicalmente; e finalmente comentar, mesmo que de forma preliminar, sua "opinião". Esperamos assim estar contribuindo para os estudos, necessários, sobre um homem que sempre se dedicou ao conhecimento e que tinha como sonho a propagação "das luzes" sobre a nação que ajudou a criar.

4. Sobre a música na formação dos índios e a percepção dos jesuítas da sua utilidade cfr. Silva, 1998, pp. 131-132; ainda sobre os índios, na necessidade de envolver os jovens no serviço musical religioso e a funcionalidade das festas, que deveriam ser "aparatosas", idem, p. 139. 


\section{Princípio de Música e Contraponto}

Antes de iniciar a análise do problema proposto, transcreveremos, na íntegra, o trecho do discurso de 24 de julho de 1818, em que o acadêmico José Bonifácio de Andrada e Silva emite sua opinião sobre o livro de Rodrigo da Costa Ferreira, Princípio de Música e Contraponto ${ }^{5}$.

O Sñr. Rodrigo Ferreira da Costa apresentou a primeira parte de seus Princípios de Música e Contraponto, que derivados dos princípios mathemáticos ${ }^{6}$ da Acustica, entrão com tudo no vasto campo da Aesthetica e bellas artes. Foi esta obra lida e aprovada como merecida, e já se está a imprimir. Com effeito, Senhores, muita necessidade havia de hum bom livro elementar neste genero; mas esta falta não he só de nossos tempos, já os Gregos a exprimentavão, pois apenas possuírão alguns Tratados sobre o genero enharmonico, pela maior parte incompletos ou artificiais, como bem se colhe do que diz Aristoxenes em algumas passagens dos Livros $1^{\circ} \mathrm{e} 4^{\circ}$ dos seus Elementos harmonicos. Nesta obra do Sñr. Rodrigo Ferreira, segundo o parecer de hum bom juiz da matéria, são os preceitos e praticas da arte deduzidos de seus verdadeiros princípios por hum modo rigoroso e adequado; mostrando-se ao mesmo tempo as modificações e excepções que elles podem e devem ter. Tinhamos pois, Senhores, necessidade de huma obra como esta, que alhanasse as dificuldades, desterrasse a cega tradição, e o servil captiveiro dos mestres, e difundisse cada vez mais pela nossa gente o gosto da boa e verdadeira Musica.

E que homem em nossos dias, sem ser mais barbaro que as proprias feras, poderá ser insensivel a seus divinos encantos?. Que homem lido poderá duvidar que a Música amalga e ameiga os costumes, realça as sensações, espallha pelo povo prazeres puros e innocentes, e tem a mais desenganada influência no caráter moral e nobres paixôes da nossa alma? Para se avaliarem seus prodigiosos effeitos basta observar que a música militar, ainda em nossos dias, não só diminue no soldado as fadigas da campanha, mas em meio dos combates lhe inspira aquele ardor e hombridade que encara e despreza a mesma morte. E quanto maior seria seu effeito, se ao som dos instrumentos bellicos se unissem cantos guerreiros de algum novo Tyrteo?. Quanto fôra pois de desejar que nas escolas se ensinasse também com as primeiras lettras os elementos se quer desta divina arte; então com os primeiros principios da prosodia e pronunciação, aprenderião os

5. Este discurso está reproduzido em duas publicações: Alberto Souza, $O s$ Andradas, 1922, vol. 1, pp. 431-432, e Eduardo Cerqueira Falcão (org.), Obras Científicas e Políticas de José Bonifácio de Andrada e Silva, 1963, vol. 1, pp. 428-430.

6. Respeitaremos, nesse caso específico, a ortografia, não a atualizando, por considerar José Bonifácio homem letrado e preocupado com a boa redação, servindo deste modo de fonte para as mais diversas considerações sobre a gramática da época. Nota-se o cuidado com a ortografia nas observações da cópia que faz de um manuscrito, dedicado em 20 de setembro de 1634, ao Conde de Olivares, em que conta a viagem de um alemão pelo Brasil (AMP, coleção José Bonifácio, doc. D-69, I-1-5). 
meninos ao mesmo tempo suas verdadeiras fontes, que são a entoação e a modulação. Porém, Senhores, a Musica que eu desejaria ver ensinada nas escolas e seminarios he aquella, cujo objecto tem immediata relação e poderio em nossas sensações, para mover e abrandar o coração, enchendollo dos puros sentimentos da religiosidade e piedade, ou excitar nelle viva alegria para esquecimento de seus males. He bem triste porém o ver que commumente a Musica, este precioso Dom da Divindade, esta grande mola do coração humano, que os Gregos não sem causa chamavão no seu todo a Mestra dos costumes, esteja hoje em dia por caprichos vaidosos dos grandes Compositores, ou por nimio amor das novidades reduzidas em grande parte ás chamadas bravuras e volatas de garganta; ou transformada em affectada Dona, carregada dos arrebiques e ouropel de harmonias extravagantes e forçadas. Sei que o nosso systema harmonico differe dos modos e rythmos dos Gregos, mas não julgo impossivel que se possão aquelles transportar de algum modo para a Musica moderna, principalmente se os Grandes Compositores estudarem e analysarem melhor a natureza da antiga Musica, cujos vestigios ainda se conservam nos hymnos e threnos do canto Ambrosiano e Gregoriano. Mas quando apparecerá na Europa moderna hum novo Giomelli, ou novo Gluck, que instuído a fundo no sistema dos Gregos, e estudando ao mesmo tempo os povos cultos da Asia, quaes os Hindús, Persianos, Arabes e Chins, se atreva a tentar huma nova revolução musical, preferindo a melodia imitativa e natural ás ruidozas subtilezas e caprichos da nossa actual harmonia, que pelo menos me parece assás esteril em expressão e affectos?. Perdoai-me, Senhores, se arrastado da propria paixão sahi fóra da minha estrada. Já continuo a dar-vos conta das outras Memorias...

Este texto nos leva a esboçar, preliminarmente, uma equação que introduza a discussão de um tema que merece maior profundidade. Para tanto buscaremos na formação de José Bonifácio a presença do conhecimento musical e, na localização das idéias musicais da época, a pertinência de sua "opinião".

\section{Santos, os Homens e a Música}

Em 1763 encontrava-se a vila de Santos como sede militar e administrativa da região da extinta Capitania de São Paulo, anexada à do Rio de Janeiro em 1748. Esta condição, apesar de considerar a decadência das arrecadações da região, já que o comércio com as Minas Gerais, geradora da riqueza do reino, centralizava-se no porto da sede da colônia, ampliava a importância geopolítica de Santos, ao agrupar o comando militar do sul. Pobre porém estratégica, os seus governantes, mesmo que indiretamente, exigiam um serviço religioso que estivesse à altura do lustro de seus postos. 
A prática musical da época centralizava-se nas funções da Igreja, a música para os ofícios religiosos era uma preocupação constante das autoridades eclesiásticas ${ }^{7}$, que tinham, nos mestres-de-capela, seus representantes maiores. Estes deveriam, no cumprimento de sua função, zelar pela probidade ideológica desta, impedindo influências profanas, "cantos e vilhancicos"; a contratação e ensaio dos músicos, a guarda e composição dos "papéis de solfa", assim como a boa execução eram inerentes ao exercício do ofício (Duprat, 1985, p. 156). O poder civil, representado pelo Senado da Câmara, juntava-se, no fomento à arte, financiando as festas reais (São Sebastião, Corpo de Deus e Anjo Custódio do Reino), Constituíam-se estes dois pólos, muitas vezes disputando o privilégio de prover os cargos de mestre-de-capela, por direito, eclesiástico (Duprat, 1995, pp. 47-48), o centro de gravidade da prática da música.

Com a criação do bispado de São Paulo (1745), constitui-se, na antiga matriz da cidade, uma capela de música condizente com a condição de Sé. Chantre, mestre-de-capela, organista e moços do coro eram pagos com provimento da Real Fazenda, na época, localizada na vila de Santos $^{8}$. Segundo Régis Duprat esta seria a fase de estabilização do serviço musical na dita cidade (Duprat, 1995, p. 88), e como veremos adiante, existe um reflexo desta nova situação na vila de Santos, com a chegada do padre Faustino Xavier do Prado, vindo de Paranaguá 9 .

É Faustino Xavier do Prado, nascido em Mogi das Cruzes em 1708 e ordenado padre em 1732, o compositor das páginas de música mais anti-

7. Para Manuel Carlos de Brito, o espetáculo litúrgico constituía, no reinado de Dom João V, o modo pela qual se representaria a eloquência do absolutismo (Brito, 1994, p. 97).

8. DAESP, Real Fazenda de Santos, cx. 242. Folha de despesas assinada por José Ribeiro de Andrade onde constam os pagamentos das côngruas do corpo eclesiástico da Sé de São Paulo.

9. A permuta, ou simples transferência de padres de Paranaguá e Santos era reincidente. Em 1732, José Rodrigues França, indisposto com a comunidade santista (AHUL, São Paulo, cat. d. 784), troca de paróquia com o padre Francisco Barbosa, este provido em Paranaguá, por sua vez, ao deixar Santos, em 1750, dá lugar a Faustino Xavier do Prado, na época coincidentemente encomendado em Paranaguá (ACMSP, PHGM, João Rodrigues França, 1-20-198). Dado relevante, para futuras considerações, é que Francisco Barbosa, salvo erro de ser homônimo, estaria provido como vigário encomendado de Conceição de Guarulhos na década de 1710, mesma paróquia que serviria Faustino na década de 1740 (DAESP, Inventários não publicados, ordem 517, Baltazar Bueno da Veiga, doc. 16,1741$)$, seria mera coincidência ou existiria uma conduta na provisão 
gas até o momento encontradas no Brasil (Duprat, 1985, pp. 9-17). Chega a Santos em 1750 onde permanece até 1760 , quando é nomeado cônego na Sé de São Paulo. Sua principal obra, na vila de Santos, foi a constituição da "Colegiada da Matriz"10, ares de catedral à matriz do porto do comércio, e das armas! ${ }^{11}$. O padre Faustino, vigário da vila que, na prática, era a sede administrativa da região sul da colônia, sente a exigência de um serviço religioso maior, estabelece um coro de capelães, que segundo ele próprio era um coro "... a qual vulgar e geralmente se chama Colegiada, para nela quotidianamente se recitarem as horas canônicas e os ofícios divinos..."12, que exigiam capelães habilitados em música, mais "moços do coro" e mestre-de-capela ${ }^{13}$.

Para o financiamento dos capelães, Faustino lança mão de uma herança no valor de oito mil cruzados, a ele deixada, por Domingos João. Corpo não provido pela Fazenda Real, deveria manter-se às suas custas, vemos assim, como no dia quatro de maio de 1752, juntam-se, na sacristia da matriz santista, o padre Faustino Xavier do Prado e mais:

[...] João Floriano Ribeiro de Andrada e Silva, Ângelo Gomes Ribeiro, Jerônimo Luciano Perez, Tomé de Castro Carneiro, João Lim de Córdova e Salvador Pereira de Jesus, capelães da nova Colegiada ereta nesta Igreja Matriz e da outra José Pereira da Silveira Surdo, como testamenteiro de Domingos João, natural de Avelaens Damboa [...] deixa para a fundação e sustentação da Colegiada que se pretende erigir e fundar na Matriz desta vila oito mil cruzados, que me é a dever a juros de seis a quatro por cento o Sargento-mor Antônio Ferreira Lustoza com obrigação de anualmente de se me dizer, no altar do santíssimo sacramento [...] a qual a quantia de dinheiro porão os meus testamenteiros a juros com toda a segurança necessária para o seu rendimento se me fazer anualmente os sufrágios ${ }^{14}$.

sucessória de padres, pois, assim como Francisco Barbosa, Faustino Xavier do Prado foi, na mesma ordem, pároco em Guarulhos, Paranaguá e Santos.

10. A colegiada de Santos assemelhava-se com às existentes na Igreja de Nossa Senhora da Candelária do Rio de Janeiro (Lange, 1968, pp. 99-142) e na Misericórdia de Salvador (Diniz, 1993, pp. 19-25).

11. O tema da Colegiada, devido à demanda de espaço que exigiria, será tratado com mais detalhes em uma publicação em preparação.

12. ACMSP, PGA, autos cíveis, interior-Santos "Autuação de uma petição e conta corrente" 1793, p. 21.

13. Não se pode deixar de citar a necessidade dos clérigos acudirem às funções musicais, visto que os homens voltaram-se para as minas, na esperança do ouro redentor. Jaime Diniz faz uma cuidadosa explanação das características destas colegiadas, da mesma forma sobre a atuação dos capelães como músicos (Diniz, 1993).

14. ACMSP, PGA, autos cíveis, interior-Santos, "Autuação de uma Petição e conta Corrente", 1793. 
No processo de liquidação dos bens da Colegiada, extinta em 1779, revela o então cônego Faustino que, apoiado nos juros do dinheiro herdado, assim como nos alugueis de casas ${ }^{15}$, constituinte do patrimônio da dita instituição, "se foram continuando os ofícios divinos muitos anos, satisfazendo aos coreiros a côngrua anual de cinqüenta mil reis estipulada pelo mesmo reverendíssimo $\mathrm{Sr}$ a cada um deles, e também pagandose a dois moços do coro, e ao sineiro..." ${ }^{16}$. Esta era a estrutura da dita colegiada, que ao comparar-se com a das Sés percebe-se a falta do organista e mais dois moços do coro; o estipêndio dos capelães equiparava-se ao das catedrais, $50 \$ 000^{17}$, o que comprova a intenção de aparelhar a vila com os serviços religiosos compatíveis com as principais cidades brasileiras. Das pessoas declaradas como capelães, em 1752, temos a certeza de que quadro eram músicos com confirmação de ofício: Faustino Xavier do Prado, Ângelo Gomes Ribeiro ${ }^{18}$, João Lim de Córdova ${ }^{19}$ e João Floriano de Andrada e Silva, tio de José Bonifácio, de quem trataremos adiante.

Como foi dito, extinta em 1779, a Colegiada já dava sinais de desfiguração dois anos antes, quando o $3^{\circ}$ bispo de São Paulo, Dom frei Manuel da Ressurreição, demonstrava no Relatório Geral da Diocese de São Paulo $^{20}$, que não haveria clérigo que aceitasse trabalhar no coro pelo estipêndio pago, estando assim ela sobrevivendo graças a atuação de cinco seculares que a mantinham funcionando de forma precária. Entretanto, para o presente texto, o importante é a constatação da ativi-

15. Este sistema de captação de recursos, através de juros por empréstimos, era muito usual para a manutenção das irmandades, assim como o aluguel de casas que eram deixadas como herança pelos irmãos devotos. Faustino justificou a decadência da Colegiada santista a partir da alteração na taxa de juros que eram a seis e quarto (sic) por cento, e por que depois por ordem de sua Majestade Fidelíssima se diminuíram a cinco por cento e assim não eram bastantes para a satisfação das tais côngruas (ACMSP, idem, p. 64), acrescenta também, que as casas eram velhas e pouco rendiam. Entre estas, que pertenciam ao legado da Colegiada, estava a que foi vendida ao mestre-de-capela da Sé paulistana, André de Moura (ACMSP, idem, p. 33). Entre as várias considerações possíveis sobre o exemplo, destacamos que não havia o discernimento entre o bem público e o privado, o que se percebe é que Faustino administrava os bens da Colegiada confundindo-os como próprios.

16. Idem, p. 64.

17. DAESP, Real Fazenda de Santos, cx, 242.

18. ACMSP, PHGM, Ângelo Gomes Ribeiro, 1-14-160, 1748.

19. ACMSP, PGA, Crime - Santos, padre Francisco Ferreira Matoso, 1765.

20. Righsp, vol. IV, p. 399. 
dade musical na vila natal de José Bonifácio, que nasce e passa a infância tendo na matriz um serviço estável de música, representado no estabelecimento da Colegiada; esta seria o caminho para um contato constante com a música, da mesma forma que para uma possível iniciação nas regras da arte musical, pelas mãos de um mestre-de-capela.

Os mestres-de-capela tinham por tradição ensinar meninos ${ }^{21}$ nas matrizes ou conventos religiosos; para exemplificarmos melhor o problema da educação musical, recorreremos a um contemporâneo de José Bonifácio, Jesuíno Francisco de Paula Gusmão, ou padre Jesuíno do Monte Carmelo (1764-1819) ${ }^{22}$, que, segundo suas próprias palavras teria aprendido, no convento do Carmo santista, a arte da música (Andrade, 1945, p. 147). Na matriz, existe uma lacuna de informações que turva a certeza de quem poderia ocupar-se da música polifônica entre 1765 até 1775 , ano em que Dom Manuel da Ressurreição passaria provisão para o cargo de várias matrizes do bispado de São Paulo, como reclama ao Rei, o então governador da Capitânia, Luís Alberto Botelho de Souza Mourão, o Morgado de Mateus ${ }^{23}$. Acreditamos que, a partir da iniciativa do bispo, André de Moura tenha sido nomeado, não descartando a possibilidade de já estar exercendo a função de forma não oficial. Outro "candidato" ao posto seria João

21. Manter escolas públicas para a educação de meninos era uma das tarefas dos mestres-de-capela. Em São Paulo tivemos dois músicos que exemplificam o caso: Manuel Lopes da Siqueira(1661-1716?), mestre-de-capela da Matriz de São Paulo de 1680 a provavelmente 1716, que formou uma geração de músicos que monopolizaram a atividade musical na vila paulistana na primeira metade do século XVIII; junto aos alunos de Siqueira, encontramos, cantando em ofícios religiosos, o padre santista Francisco de Novilher (DAESP, Inventários não publicados, Manuel Pinto Ribeiro, ord. 506, 1726), importante figura do clero da vila de Santos na década de 1740. Outra escola, também orientada pelo mestre-de-capela, da então Sé de São Paulo, foi a de André da Silva Gomes (Duprat, 1995, pp. 26-27 e 70-71). Em Santos, André de Moura (1726-1810) em 1776 acolhe, como agregado, José, menino do coro (DAESP, maços da população, rolo 173); ensinar meninos, albergando-os em sua casa, era fato comum neste tipo de atividade, expostos ou pobres encontraram, na atividade musical, a porta de um futuro mais próspero; os mestres-de-capela, na inevitável compensação, reduziam os custos de sua atividade, empregando aqueles que abrigavam e educavam.

22. Interessante é que Jesuíno Francisco de Paula Gusmão, um ano mais novo que José Bonifácio, também deixa a vila santista na década de 1780 , indo para Itú, onde funda, mais tarde, um grupo que ficaria conhecido como os padres do Patrocínio, albergando entre outros a Diogo Feijó, ferrenho adversário de Andrada, quando este era tutor dos filhos de D. Pedro I.

23. AHUL, São Paulo, cat. doc. 2666. 
Lim de Córdova, homem formado no colégio São Miguel dos Jesuítas, assim como Manuel Francisco Villela ${ }^{24}$, Ângelo Gomes Ribeiro e provavelmente Frei Gaspar da Madre de Deus (Madre de Deus, 1975, p. 9). Instruído, Córdova tinha caligrafia desembaraçada, foi escrivão dos resíduos em $1754^{25}$, mais tarde do próprio cartório eclesiástico, sendo nomeado em 1765 , coadjutor da Matriz ${ }^{26}$; havia sido mestre-de-capela da colegiada e do Colégio de São Miguel dos jesuítas, fato que se revela no tumultuado caso de acusações contra Francisco Ferreira Matoso, originadas pelo então governador da praça de Santos, Manuel Martins dos Santos ${ }^{27}$.

Supõe-se, também, no caso de Córdova, a atividade musical sendo exercida por um homem articulado e instruído, partícipe da administração eclesiástica local; formação distinta dos competentes músicos mineiros da época, que independente de sua capacidade musical, eram em sua maioria mulatos e que, através da música, galgaram certa posição social; aliás esta distinção é uma característica paulista, ao contrário da

24. Manuel Francisco Villela é figura de relevo na segunda metade do século XVIII na vila. Descendente de Amador Bueno da Ribeira, o padre Villela foi vigário da vara de Santos em 1757. Citado por José Feliciano Fernandes Pinheiro, Visconde de São Leopoldo, o professor que gentilmente o albergou, quando da falta de mestres na vila, devido à expulsão dos jesuítas em 1759 (FAMS, Memórias para História de Santos - José da Costa e Silva Sobrinho, vol. 113, p. 8). Vale notar que o padre assina, em 1800, juntamente com André de Moura, recibo de quatro mementos cantados no enterro de Ana Joaquina Lustosa (Idem, vol. 39, pp. 114 e ss.)

25. ACMSP, PGA, crime, interior - Santos, padre José Rodrigues Sanches, 1754.

26. DAESP, maços da população, rolo 173. Neste ano, 1765, não há indicação de mestre-de-capela, André de Moura, que ocupa o cargo de 1775 a 1810 era, então, registrado como homem que vivia do "ofício de pintor", ocupava-se de pintar letreiros em faixas, portas comerciais, estandartes religiosos etc. Em 1775, vivia de sua "arte de pintar", Francisco Xavier Gonçalves (ACMSP, maços da população, rolo 173), distinção na discriminação dos ofícios caracterizando a atividade artística. O mesmo Francisco Xavier, avalia o valor de imagens no inventário de André de Moura, ...imagem da Senhora do Parto com o seu menino tudo feito em Madeira altura de três palmos e meio mais ou menos que foi visto e avaliado pelo mestre escultor e pintor $\mathrm{Fr}^{\circ}$ Xavier Gonçalves em preço de seis mil e quatro centos e com a mesma quantia a margem se ache (FAMS, Material para a História de Santos, - José da Costa e Silva Sobrinho, vol. 42, p. 284).

27. Este caso revela a interferência dos poderes não eclesiásticos na nomeação do cargo de mestre-de-capela. Conta Francisco Ferreira que João Lim de Córdova teria sido provido justamente por orientação do governador e que ele mesmo houve de destituí-lo, através do vigário Domingos Moreira e Silva (ACMSP, PGA, crime, interior - Santos, padre Francisco Ferreira Matoso, 1765). 
chaga "andariega" vista por Francisco Curt Lange (Lange, 1966, pp. 910). Como luz aos céticos, o exemplo do padre Ângelo de Siqueira, mestre-de-capela da matriz de São Paulo na década de 1730 (Duprat, 1995, p. 30); o padre qualifica-se, também, como escritor, de sua autoria existem seis livros conhecidos, classificados como textos populares de devoção (Moraes, 1969, p. 343), destacando: Botica Preciosa e Thesouro Precioso da Lapa de 1754, Penitente Arrependido e Fiel Companheiro. Para se Instruir uma Alma a Fazer uma Boa Confissão sem Pejo de 1758 e Livro do Vinde e Vede e do Sermão do Dia do Juízo Universal, de 1759. O músico, descendente de família da baixada santista ${ }^{28}$ que migrara da ilha de São Vicente para São Paulo na década de $1660^{29}$, dando ao planalto paulista substancial número de mestres-decapela ${ }^{30}$, ocupou, entre outros, o cargo de missionário do Bispado de São Paulo, na época do $1^{\circ}$ bispo, Dom Bernardo Nogueira; promotor de resí-

28. Manuel Lopes da Siqueira casa-se com Esperança Gomes da Costa, irmã do padre Antônio Raposo, que estava provido como vigário da matriz de São Vicente na primeira metade do século XVII (Anuário da Diocese de Santos, 1947, p. 113), e que por ter fama de cristão novo foi expulso da vila depois de um motim do povo, (ACMSP, PHGM, Ângelo da Siqueira, 1-8120, 1732, p. 21). Filho do casal citado, o mestre-de-capela da matriz de São Paulo de 1681 a 1716, Manuel Lopes de Siqueira, sempre identificou-se como natural da cidade de São Paulo, porém, é o próprio vigário da matriz paulistana na época, Bento Curvelo Maciel, que atesta que não poderia confirmar as acusações que pesavam sobre $o$ sangue dos Siqueira, mas, tinha certeza que o músico não era natural de São Paulo (Camargo, 1953 , v. 3, p. 284). Supomos que, para afastar a mácula da acusação, Manuel Lopes teria omitido sua origem santista, que fatalmente o ligariam à fama do padre Raposo, porém, no testemunho de Margarida Coelho da Fonseca (ACMSP, Ibidem, p. 24), a confirmação de que Esperança Gomes e sua família passaram a São Paulo depois de viverem muitos anos na vila de Santos, ... a qual ela testemunha conheceu ainda de vista ser casada na vila de Santos com o sobredito Manoel Lopes de Siqueira, e de lá vinham em algumas festas a São Vicente, a visitar o Padre Antônio Raposo irmão inteiro da dita Esperança da Mota, o qual nesse tempo era vigário encomendado na dita vila de São Vicente, e deste se dizia também era cristão novo, mas que a dita Esperança da Mota nunca morou com seu marido em São Vicente, mas de Santos onde era moradora e se passara com seu marido e filhos para São Paulo.

29. ACMSP, PHGM, Ângelo de Siqueira, 1-8-120, 1732.

30. Do consórcio de Manuel Lopes de Siqueira e Esperança Gomes nasceram, Antônio Raposo de Siqueira, Manuel Lopes de Siqueira, Francisco Lopes, Simão Ribeiro, Mariano, Maria e Felipa (DAESP, inventários não publicados, ord. 494, doc. 13, 1684). Destes, como vimos, Manuel Lopes de Siqueira (filho) foi mestre-de-capela da matriz paulistana (Duprat, 1995, pp. 22-32). O padre Antônio Raposo também participa de cantorias, como em 1713 no funeral de Gaspar de Godoy Calaço (DAESP, inventários 
duos em São Sebastião ${ }^{31}$, além de ser o fundador e construtor do Seminário de Nossa Senhora da Lapa no Rio de Janeiro, atual Igreja do Carmo da Lapa (Santos, 1825, p. XVI tomo 1), a qual como que por estranha coincidência, tem zelado o edifício da atual Escola de Música da Universidade Federal do Rio de Janeiro (UFRJ), como a vigiá-la e protegê-la através dos tempos.

não publicados, Gaspar de Godoy Calaça, doc. 15175, 1713). Manuel Lopes (filho) casase com Joana de Castilho, originando a seguinte geração: o padre Manuel Lopes de Siqueira (neto), Angela de Siqueira, José Ribeiro de Siqueira e o padre Ângelo de Siqueira (DAESP, inventários do $1^{\circ}$ ofício, ord. 699, doc. 15657, 1714). Contabilizam-se, nesta linhagem, mais três mestres-de-capela: o padre Manuel Lopes de Siqueira (neto) (Duprat, 1995, p. 27), José Ribeiro de Siqueira, que ocupa o cargo em Santana do Parnaíba (DAESP, inventários do $1^{\circ}$ ofício, ord. 654 , doc. 14148,1736 ), este último pai do também mestrede-capela da mesma vila de Parnaíba, Ângelo de Siqueira Ribeiro do Prado (DAESP, inventários não publicados, José Garcia Ribeiro, doc. 15182) frequientemente confundido, nos dicionários biográficos (Blake, 1969, p. 89), com seu tio, Ângelo de Siqueira, titular de semelhante cargo na matriz paulistana de 1725 a 1737(?) (Duprat, 1995, p. 30). Trataremos, em pouco espaço, de desfazer este equívoco. Ângelo Ribeiro do Prado, segundo Silva Leme, filho de José Ribeiro de Siqueira e Joana do Prado, era casado, em 1758, com Martinha Paes da Silva (Silva Leme, 1905, cap. III, p. 169); em 1744 passa recibo como mestre-de-capela na vila de Santana do Parnaíba, como já foi documentado acima. Esta coincidência de atividades pode ter sido determinante no erro dos biógrafos, além dos laços familiares. Por outra parte, vejamos Ângelo de Siqueira: nos frontispícios de seus livros ele creditava-se como missionário apostólico; vemos que, no ano que seu sobrinho era o mestre-de-capela de Parnaíba, 1744, o padre recebia a confirmação para missionário diocesano e visitador, função que acrescentava-lhe o título de doutor (Camargo, 1953 , vol. 3, p. 397) e que incompatibilizava-o no exercício da mestragem. O estado civil de Ângelo de Siqueira Ribeiro do Prado, casado em 1758, é absoluto na distinção entre os dois, e mais, nesta data, encontrava-se o missionário em Portugal, onde editaria seus livros. Outras referências biográficas elucidativas podem ser encontradas no trabalho do Monsenhor Silveira Camargo, A Igreja na História de São Paulo (Camargo, 1953, v. 3), que, ademais, considera o dito padre como uma das figuras exponenciais do clero paulista do século XVIII.

31. DAESP, inventários não publicados, ord. 516 , doc. 20 e 21, 1738. Nesta paróquia era padre encomendado, na época, o protonotário apostólico Dr. Manuel Villela Bueno, santista, futuro cônego e tesoureiro-mor do cabido de São Paulo, tio do vigário da vara de Santos em 1757, Manuel Francisco Villela (Pompeo, 1929, vol. 1, p. 57). 


\section{Os Andrada}

O espírito especulativo de José Bonifácio, original da ânsia de conhecer as coisas do mundo, nasceu certamente do convívio familiar que lhe teria inspirado os padrões de instrução e de amor à vila que o aconchegou. Assim dá a entender Francisco Xavier da Costa Aguiar, seu cunhado, em carta de 1801 com comentário domésticos:

[...] A 19 de novembro próximo futuro, faz quinze anos que me recolhi a esta sua casa da minha digressão a Lisboa, e como o meu gênio nunca foi de viver em terra pequena, onde só os incomparáveis merecimentos de sua linda mana me puderam trair, trabalhei nos projetos em querer mudar-me para o Rio de Janeiro, chegando a fazer partidos a $\mathrm{Sr}^{a} \mathrm{D}$. Maria Barbara minha sogra, para reduzir os seus bens a dinheiro, afim de nos mudarmos todos para o Rio ou Lisboa, aonde faríamos um estabelecimento mais sólido por muitos diferentes meios, pois não me satisfazia o ar úmido que respirava na atmosfera da pequena e pantanosa vila de Santos, pois nestas capitanias descobria os [...] vícios de diversas incolher.cas (sic), mas tudo foi debalde, pois sua mana, era a primeira que pelo amor da Pátria, descorava os meus projetos, com algumas imagens que me fizeram ceder $[\ldots]^{32}$

A fortuna do pai, Bonifácio José, fillho mais novo de José Ribeiro, aliada à boa formação familiar, foram os ingredientes necessários para o desenvolvimento da criança nascida em 1763. A distinção familiar notase já em José Ribeiro de Andrada, patriarca dos Andrada, que em 1722 era capitão de ordenanças (cargo que ocuparia Bonifácio José em 1776) e escrivão da Fazenda Real de 1730 até $1752^{33}$. Teve nos tios exemplo de educação sólida. Formado médico em Coimbra, José Bonifácio de Andrada, cirurgião do presídio de Santos e posteriormente clérigo do hábito de São Pedro, e Tobias Ribeiro de Andrada, tesoureiro-mor do cabido da Sé, posto que seria ocupado também por Faustino Xavier do Prado, juntavam-se a João Floriano de Andrada e Silva ${ }^{34}$, sobre o qual recai o primeiro indício de formação musical dos Andrada. Batizado em 1721 , obtém ordens religiosas no ano de 1752 , justificando ser formado

32. BN, seção de manuscritos, doc. I-27-1.

33. RIHGSP, vol. XXVI, p. 299.

34. Há que se fazer uma ressalva e justa homenagem à detalhada e criteriosa biografia dos Andrada feita por Alberto Souza, servindo de referência a qualquer estudo sobre a referida família (Souza, 1922, vol. 1, pp. 278 e ss.). 
em gramática e filosofia ${ }^{35}$, ter mais de 26 anos, pais decrépitos com gosto pela ordenação, e a Igreja ter falta de sacerdotes. Suas aptidões literárias revelam-se nos testemunhos do processo de Genere, Antônio Toledo Lara, em 1750, então com vinte seis anos, filósofo e teólogo ${ }^{36}$, futuro cônego, a quem Pedro Taques "não reconheceu superioridade de conhecimento dela em outro algum de seu tempo" (apud Pompeo, 1929, vol. 1, p. 158) atesta que o suplicante era bom gramático e filósofo "e que sabe por ter visto obras suas e ter tratado com ele"37; ademais, o fato de ter conhecimento musical, como comprova o subchantre da Sé de São Paulo, o antigo coadjutor da matriz da vila de Santos, José Rodrigues Paes, que é conciso ao afirmar que o examinou em cantochão em 23 de maio de 1750 e o julgou "capaz de exercitar qualquer função de altar, pois é muito bem entrado e com bastante disposição para entender as regras gerais da cantoria"38. No mesmo ano de sua ordenação, 1752 , ingressa como capelão da colegiada da matriz santista.

$\mathrm{Na}$ geração seguinte encontramos o padre Patrício Manuel de Andrada e Silva, primogênito de Bonifácio José de Andrada e Maria Bárbara, envolvido com atividades musicais, cantando nos ofícios fúnebres. Batizado em 24 de março de 1760, na matriz de Santos, em 1776, Patrício Manuel já era clérigo tonsurado na mesma igreja ${ }^{39}$. Requer ordens sacras em 1779, juntamente com seus irmãos, os quais, segundo

35. Os filhos de José Ribeiro estudaram no colégio dos jesuítas de São Paulo, como fica evidenciado na declaração de José Bonifácio de Andrada, dizendo que antes de passar a Coimbra, foi estudante de gramática e filosofia no dito colégio (ACMSP, PHGM, José Bonifácio de Andrada, 1-1-203, 1752). Soma-se a isto o teor do testemunho de Felipe Mendes Santiago, que conhecia João Floriano há pouco mais de sete anos (1743), quando veio estudar em São Paulo. Fica a hipótese de que primeiramente a família iniciou-se no colégio santista, tomando-se como base a petição de uma certidão de proficiência em latim, do próprio João Floriano, feita ao reitor do colégio São Miguel, padre Miguel Amaro, em 1750 (Ibidem). O "binômio" Santos - São Paulo estende seu âmbito também para a educação; é impossível sistematizar qualquer assunto sobre a história das duas localidades sem considerar este fenômeno: a dependência mútua estabelece um quadro de influências que gera um dinâmico trânsito de ação e reação, ondas gravitacionais que sobem e descem a Serra do Mar (Petrone, 1966). Se Santos era a chave de entrada para o sertão das minas (AHUL, São Paulo, cat., doc. 103), São Paulo era a porta!

36. RHIGSP, vol. IV, p. 356.

37. ACMSP, PHGM, João Floriano de Andrada e Silva, 1-1-203, 1748.

38. Idem, ibidem.

39. DAESP, maços da população, rolo 173. 
Alberto Souza, fizeram esse trâmite na intenção de demonstrar limpeza de sangue (Souza, 1922, p. 306). Ordena-se em 1783, contando, em seu processo de Genere, com o reconhecimento de Antônio de Oliveira Costa, subchantre da Sé de São Paulo e antigo mestre-de-capela (Duprat, 1995, p. 55); nos anos de 1790, segue, o padre Patrício Manuel, para ser vigário em Apiaí.

O documento mais antigo, que comprova as atividades musicais do irmão mais velho de José Bonifácio data de 1800, quando ele se junta ao mestre-de-capela André de Moura e ao padre Manuel Ângelo Figueira de Aguiar - este, parente dos Andrada - entre outros, para cantar mementos nos ofícios fúnebres de Ana Joaquina Lustoza. Passa um recibo que certificava:

Per sancta Dei Evangelica que disse uma Missa de Corpo presente de esmola de 640 reis e assim, mais oito missas de esmola de 400 reis no oitavário seguinte. Assisti ao oficio, recomendação e quatro mementos cantados no enterramento da falecida D. Ana Joaquina Lustoza por quem foram as ditas missas; e de tudo fico pago com $6 \$ 800$ reis que recebi e satisfez seu testamenteiro ${ }^{40}$.

O que poderia parecer uma eventualidade, a participação do padre Andrada no coro, intenção freqüente do testador, que pedia a todos os clérigos presentes que assistissem à cerimônia fúnebre, somando a isto, a obrigatoriedade de serem, os padres do hábito de São Pedro, suficientes, em tese, de conhecimentos musicais, leia-se cantochão, reitera-se sete anos mais tarde, quando novamente ao lado de André de Moura, no enterro de Bernardino Pires Viana, em 1807, diz que recebeu ... "640 de esmola de recomendação, e um memento o que juro per sancta dei Evangelia". Ressalta-se que do grupo de 1800 , apenas comparece juntamente com Patrício, o padre Antônio Pereira Jorge; participa também do ofício o jovem de dezessete anos, João Cardoso de Menezes e Souza ${ }^{41}$, pai homônimo daquele que mais tarde seria o Barão de Paranapiacaba, poeta, tradutor, e que participou ao lado de José de Alencar da comissão que analisava e subvencionava obras literárias-teatrais; encontramos em Machado de Assis referências sempre elogiosas sobre o santista, como

40. FAMS, Memórias para História de Santos - José da Costa e Silva Sobrinho, vol. 39 , p. 118.

41. Idem, vol. 40, p. 17. 
uma crônica ${ }^{42}$ sobre um sarau literário em homenagem ao poeta da $A$ Harpa Gemedora; na ocasião, recebe, do grande escritor, o epíteto de "homem de letras" (Assis, 1957, v. 1, p. 255). e mais a distinção de "poeta mavioso e prosador correto" (Assis, 1957, v. 1, p. 87).

Voltando ao caso de Patrício, poderíamos supor, ainda, que os dois ofícios documentados não o fariam depositário das qualidades de músico, porém aos recibos arrolados podemos incluir, vinte e seis anos após, no funeral de Rosa Maria Leite, outro do seguinte teor:

[...] Despesas que tenho pago pertencentes ao enterro, depósito e funeral da mesma falecida // Pelo que paguei ao Rev. ${ }^{\circ}$ Patrício Manuel de Andrada $1 \$ 920$ // Ao reverendo Manoel Ângelo Figueira de Aguiar $\$ 960 / /$ Ao rev. Joaquim Bento do Carmo $4 \$ 480 / /$ Ao Rev. ${ }^{\circ}$ Caetano Francisco de Assis $1 \$ 600 / /$ Aos dois sacristãos do depósito, enterro e ofício 5\$920 // Pelo que paguei a Manuel Joaquim da Trindade da música para o depósito, enterro e ofício $48 \$ 000 / / 16$ de julho de 1833 .

Aos padres Patrício e Manuel Ângelo somam-se o padre Joaquim Bento do Carmo, neto de André de Moura por parte de Lourenço Justiniano Rosa, este, herdeiro do ofício e do rabecão do antigo mestrede-capela; e Manuel Joaquim da Trindade, provável descendente de Moura pela paternidade de seu filho e igualmente mestre-de-capela de Iguape, Mariano da Trindade Moura ${ }^{43}$. A soma despendida com o mestre-de-capela, $48 \$ 000$ é indício que concorreram à cerimônia músicos arregimentados por Manuel Joaquim da Trindade, constituindo uma pequena orquestra, geralmente atrofiada no naipe de sopros (Duprat, 1995, pp. 71 e 80).

Patrício Manuel, assim como seus irmãos mais célebres, atua na política, mesmo que de forma modesta; em 1829, elege-se para vereador na gestão que ficaria conhecida como a "Câmara dos padres" (Souza, 1922, p. 307), juntamente com Manuel Ângelo Figueira de Aguiar: companheiros de sangue, de batina e de cantoria! Participa também da mesa do conselho deliberativo da "Sociedade Philantrópica", que tinha fins de auxiliar a Santa Casa de Misericórdia, casa da qual o padre era capelão, sucedendo-o Joaquim Bento do Carmo e João Cardoso de Menezes e

42. Crônicas escritas na Semana Ilustrada de 1861 a 1864, nomeadas "Crônicas do Dr. Semana".

43. ACMSP, PHGM de Joaquim Mariano da Trindade, $\mathrm{n}^{0}$ 2-45-1111, 1816. 
Souza $^{44}$. Precipita-nos a conclusão fácil ao olhar os padres capelães da Misericórdia, porém não podemos nos furtar, também, de supor que a convivência nos coros da Igreja tenha contribuído para a sucessão na capelania da Santa Casa.

\section{São Paulo, o Frei, e os Músicos!}

Aos 14 anos de idade, o jovem Bonifácio sobe a serra, retornando apenas em 1819; começará a se preparar para uma grande carreira acadêmica, e nos seus primeiros passos encontrará a contribuição do $3^{\circ}$ bispo de São Paulo, Dom Frei Manuel da Ressurreição. Pouparemos esforços em escrever sobre essa relação, já que está minuciosamente estudada nas mais diversas biografias e trabalhos sobre o jovem santista. Vale ressaltar, no entanto, o texto de Brenno Ferraz do Amaral que, ao apresentar o bispo, destaca como o jovem foi partícipe de uma revolução que recentemente chegava ao Brasil: as reformas educacionais do Marquês de Pombal. Mostra ainda as possibilidades que teria tido o Andrada na consulta de uma biblioteca ricamente ilustrada, pertencente ao bispo (Amaral, 1968, pp. 41-60).

No projeto de modernização da Sé paulista de Dom Manuel da Ressurreição, constava a reestruturação do serviço musical. E foi assim que trouxe consigo, desde Lisboa, um jovem músico: André da Silva Gomes. Nascido na metrópole portuguesa, no ano de 1752, Silva Gomes chega ao Brasil juntamente com o bispo em 1774, com a responsabilidade de não apenas dirigir a música, mas também de dotar a Sé de novos ares; compor e ensinar era a árdua tarefa, São Paulo era limitado de recursos e possibilidades, vivia uma insipiência artística, mesmo em relação aos outros centros brasileiros e contava com a oposição do governador à época, que preferiria, no cargo de Silva Gomes, o mineiro de Sabará, Antônio Manso da Mota, vindo da Bahia e nomeado, pelo Morgado de Mateus, diretor da casa da ópera ${ }^{45}$. Justificava que a música de Manso

44. AISCMS, livro de certidão de missas dos irmão defuntos de 1837 a 1875.

45. Nestas "casas da ópera", que se espalham pelas principais cidades brasileiras a partir da década de 1760, representava-se preferencialmente o gênero da ópera bufa, assim como, provavelmente, as obras de Antônio José da Silva, o judeu (Azevedo, 1956, pp. 18-22). Segundo o autor citado, em São Paulo, em 1770 haveria sido encenado a ópera 
era mais do gosto popular (Duprat, 1995, pp. 51-52). O Morgado de Mateus, ademais, contestava a jurisdição do prelado para nomear mestres-de-capela ${ }^{46}$.

Apesar de não haver nenhum documento que encontre o jovem santista como aluno do mestre-de-capela português, vemos, como hipótese, a sua participação nos ofícios da Sé, cantando e educando-se, assim como Patrício, reconhecido pelos capelães e subchantre do cabido.

Outro músico, este conhecido da família Andrada, residente em São Paulo, era o cônego e antigo pároco da vila de Santos, Faustino Xavier do Prado. O relacionamento de Bonifácio José com o vigário tinha um matiz no âmbito profissional. Servindo na Real Fazenda de Santos, na década de 1760 , o almoxarife Bonifácio José 47 conviveu com o escrivão Ângelo Xavier do Prado (1712-1769) ${ }^{48}$, irmão do referido cônego que, assim como a repartição da fazenda santista, muda-se nos meados de 1766 para São Paulo. A chegada dos irmãos Andrada na capital encontra, na figura do cônego, rosto familiar, podendo ter facilitado a proximidade com o bispo.

Partiria, poucos anos mais tarde, o jovem José Bonifácio para seus estudos em Lisboa.

\section{Portugal, Terra dos Napolitanos!}

A casa de Bragança sempre se caracterizou por uma grande afinidade com a arte da música. Essa característica se evidencia na vida de

diretor da casa da ópera paulistana, Antônio Manso da Mota, fazia-se representar, em 1760, Alexandre na Índia, tema usado na época por Schiassi, Fabri e Jommelli, este, preferido de José Bonifácio (Duprat, 1985, p. 27).

46. Todo esse cenário musical está magistralmente resolvido pelo musicólogo Régis Duprat, no seu livro Música na Sé Colonial de São Paulo, referência obrigatória. Economizamos, assim, as citações e remetemos ao texto integral, na tranquilidide de ser ele absoluto em suas averiguações.

47. AHUL, São Paulo, cat., doc. 2166.

48. O primeiro documento de que se tem notícias sobre Ângelo Xavier do Prado como escrivão da Real Fazenda de Santos data de 1753 (AHUL, São Paulo, cat., doc. 2058). Acreditamos que deva ter substituído José Ribeiro de Andrada, devido à sua última provisão para o cargo datar de 1753 (RIHGSP, vol. XXVI, p. 299). Encontra-se ainda no exercício de sua função $\mathrm{em} 1766$, quando copia o registro, que havia feito em 
Dom Teodósio II, $7^{\circ}$ Duque de Bragança, que funda o Colégio dos Reis em Vila Viçosa e deixa, pelas suas próprias palavras, como a melhor herança a seu filho Dom João IV (1604-1656) a capela de música de sua casa. Por sua vez, quando sobe ao trono na restauração do reino de Portugal em 1640, Dom João IV se torna um ativo protetor dos músicos, não só cria um considerável acervo bibliográfico musical, como se cerca dos melhores compositores e intérpretes portugueses, fazendo de Vila Viçosa uma escola modelo. Em sua administração criou-se a Irmandade de Santa Cecília, que albergava os músicos, sendo também responsável pela manutenção do nível artístico de seus irmãos, através de seletivo exame de admissão. Essa associação defendia, ademais, os interesses profissionais da classe. Este cuidado, dedicado pelo monarca à arte da música, com certeza, deve ter se refletido na organização das capelas musicais da nova Lusitânia.

Dando um pequeno salto no tempo, encontraremos em Dom João V (1689-1750) um sucessor na coroa e no culto da música, este a inclui no processo de afirmação do poder absolutista, através das instituições religiosas e espetáculos litúrgico, como nos mostra Manuel Carlos de Brito (Brito, 1994, p. 97), criando, consequentemente, em 1713, o Seminário Patriarcal de Lisboa, casa destinada ao ensino da música religiosa (Santos, 1942, p. 67). Segundo a análise de Brito, a capela de música papal era o modelo a ser seguido, sendo para isso determinante a atuação da representação diplomática portuguesa em Roma, que teria fácil circulação nesses ambientes musicais. Arregimentaram-se vários cantores, e até mesmo o mestre-de-capela papal, Domenico Scarlatti, que chega a Lisboa em 1719 permanecendo sete anos a serviço do monarca português (Brito, 1994, p. 98). Scarlatti trazia na bagagem o peso da escola napolitana de Alessandro Sacarlatti, Provenzale, Stradella, Pergolesi entre outros; era o encontro da antiga escola polifônica espanhola-portuguesa com a italiana

1765, da patente do governador Luís Alberto de Souza Mourão (DI, vol. XV, p. 23). Problema musicológico centra-se no reconhecimento de Ângelo como compositor do $E x$ tratactu sancti Augustini, que leva o seu nome. Apesar dos manuscritos, encontrados em Mogi pelo pesquisador Jelson Bitran da Trindade (Trindade, 1984, pp. 15-20) indicarem o funcionário real como o autor da dita música, paira a dúvida, levantada por Régis Duprat, sobre a sua veracidade! 
das óperas e oratórios. Dom José I, sucessor de D. João V, continuaria a política de seu antecessor, porém, a ópera, em Portugal, já não tinha o mesmo brilho desde o terremoto de 1755, quando desmoronou a Ópera do Tejo (Brito, 1994, p. 102); mesmo assim, chegaram à casa real, residindo ou em forma de pensão, dois dos mais celebrados compositores napolitanos, David Perez e Niccolò Jommelli (Santos, 1942, pp. 67-70).

Chega José Bonifácio a Lisboa, em 1783. David Perez, o grande nome da ópera em Portugal, havia falecido três anos antes. João de Souza Carvalho, antigo bolsista de D. José I na Itália, compunha Endemione, estreada no ano seguinte; aliás, esse compositor teve, como aluno, Marcos Portugal (Santos, 1942, p. 70), diretor musical do Teatro do Salitre em 1782, onde compunha música para as farsas portuguesas e adaptações traduzidas de óperas cômicas italianas (Brito, 1994, $\mathrm{p}$. 105). Seguindo ainda as averiguações de Brito, este músico, que conviveria com o ministro Andrada na corte brasileira, viajou, em 1792, para a Itália, e na sua volta, em 1800 substituiu, na direção musical do Teatro de São Carlos a Antônio Leal Moreira (Brito, 1994, p. 107). Podemos encontrar neste cenário dois laços envolvendo indiretamente o Andrada, que seriam, primeiro, a própria convivência, já em Portugal, com o sucesso de Marcos Portugal, e segundo, com o gosto pela obra de Antônio Leal no teatro da cidade natal da família Andrada, de propriedade de Domingos de Souza Martins, ator e diretor de uma companhia dramática; travou-se, nos idos de 1850, através de artigos no jornal local, Revista Commercial, um ríspido debate sobre o que seria a dramaturgia moderna, sendo, para uma facção, a obra de Leal referencial.

Outro aspecto da vida musical da metrópole à época da chegada de José Bonifácio, e durante sua permanência em terras lusitanas, era o sucesso, nos salões lisboetas, e mais tarde no Teatro São Carlos, de um músico brasileiro, Domingos Caldas Barbosa (1740-1800), compositor de modinhas, gênero que, como veremos, fazia o gosto da família Andrada.

\section{A Europa das Revoluções}

Na Europa, a reforma "clássica" da escola de Mannheim já havia se estabelecido. Há um bom tempo empregava-se a forma de sonata, desenvolvida após a revolução da forma ditemática de C.P.E. Bach, nos primei- 
ros movimento das sinfonias (Haydn adere em 1765 e Mozart em 1777), assim como ocorre o abandono do procedimento contrapontístico (Candé, 1994, p. 565); recordemos que Bach morre em 1750; os concertos públicos apenas começavam a se popularizar; a Gewandhaus de Leipizig havia sido recém-inaugurada em 1781; o acesso à música eminentemente instrumental, "pura",... "que não tinha função, nem no teatro, nem na igreja, era um luxo de privilegiados" (Candé, 1994, p. 544, vol. 1).

A ópera era, então, a grande atração e centro das maiores discussões teóricas da época, que desde muito dividia-se entre o estilo italiano e o francês ${ }^{49}$. Levantaram-se assim, diversas pugnas no decorrer do tempo, entre lullistas e ramistas; bufonistas e antibufonistas; e, paralelamente à chegada de José Bonifácio a Paris, gluckistas e piccinistas. Gluck, predileto do acadêmico Andrada, apresenta, em 1777, em Paris, Alceste; Piccini, no ano seguinte, para contentamento dos partidários da escola italiana, Roland.

Entre 1790 e 1792 vive o jovem estudante brasileiro, ombreando com os franceses, a efervescência da Revolução. Na razão direta da evolução dos ideais revolucionários, os temas mitológicos ou heróicos das óperas francesas, assim como suas convenções, vão caindo no esquecimento ${ }^{50}$. Rameau é abandonado para ressuscitar apenas na virada do século XIX para o XX. Compositor que sistematiza a linguagem musical tonal, com seu Tratado de Harmonia de 1722, declarava que a beleza da melodia vive no efeito da harmonia. Visão contrária tem Rousseau ${ }^{51}$, defensor da subordinação harmônica à melodia (Martins, 1990, p. 27).

49. Em rápidas pinceladas podemos caracterizar o estilo italiano na supremacia do bel canto ao drama; esta técnica desenvolveu-se principalmente em Nápoles, na primeira metade do século XVIII; modo de cantar que caracteriza-se pela virtuosidade da linha melódica, agilidade na vocalização, leveza da frase musical, era serviçal dos caprichos dos grandes cantores e das comédias de costumes. Por outro lado, a escola de ópera francesa ligava-se à aristocracia, adotando temas mitológicos ou heróicos, onde a força dramática do texto deveria prevalecer.

50. Durante a revolução, os símbolos do antigo sistema monárquico foram tratados à guilhotina, e assim foi com a estética musical de Versalhes. A França vive um momento político em que hinos, canções patrióticas e odes, assim como bailes populares, estavam mais de acordo com a atmosfera revolucionária (Martins, 1990, pp. 33-42).

51. Rousseau, que protagoniza a chamada Querela dos Bufões, tinha como hábito discutir assuntos musicais, até mesmo compor. Brilhante filósofo, assim não o era para a 
As viagens de estudo pela Europa (Paris de 90 a 92, Freiberg até 94, e pela Áustria, Alemanha e Itália até 96) colocam José Bonifácio no epicentro da vida operística, e também do Sturm und Drung. Além das agitações da revolução francesa e do domínio das óperas italianas, encontrava Mozart nas suas últimas obras para o gênero operístico: Cosí fan tutte, estreada em 1790, Viena; Die Zauberflöte, 1791 na mesma cidade e La clemenza di Tito, em Praga (Candé, 1994, p. 570). Este período, 1790 a 1796, via próximo, também, o futuro da música. Beethoven era um jovem que vivia sua formação clássica em Viena; Wackenroder (17731798), que ilustra o pensamento romântico da música, estava a poucos anos de escrever o que seria um marco para os românticos, "Fantasia em Torno à Arte de um Monge Amante da Arte" e "As Maravilhas da Arte Musical" (Fubini, 1988, p. 259). O romantismo musical vivia sua infância nos moldes clássicos, esperaria vinte e três anos até a $3^{\mathrm{a}}$ sinfonia de Beethoven, tendo como marco referencial a carta de Mozart de 1781, que escreve ao pai que a poesia deveria ser, da música, "filha obediente"; prenúncio da dominação do subjetivismo da arte musical, bastião da arte romântica. José Bonifácio, homem atento e aberto para o conhecimento, não ficaria à parte destes movimentos, considerando também, pelas suas próprias palavras, em 1819 (Silva, 1963, vol. 1, p. 460), que nunca abandonou o amor pela música, assim pode-se concluir que o discurso de 1818 fatalmente se sustentaria por um conhecimento dos movimentos musicais atuais, e não apenas na experiência de um cidadão que viveria em um país periférico da Europa, afastado dos debates contemporâneos, visão que não obedeceria a realidade portuguesa que, já no início do século XIX, via-se

música, porém, é interessante traçar um paralelo, nesta questão, entre o filósofo francês e o letrado brasileiro. Na carta de 1753, ... sobre a música francesa (Candé, 1994, p. 583, vol. 1), Rousseau posiciona-se contra os procedimentos musicais que, subentende-se, turvariam a clareza melódica assim como a expressão literária: ..."quanto às contrafugas, fugas duplas, fugas invertidas, baixos forçados e outras bobagens difíceis que o ouvido não pode suportar e a razão não pode justificar, são evidentemente restos de barbárie e de mau gosto..." "(apud, ibidem). Por sua parte, José Bonifácio reclama que a música estaria reduzida em grande parte às chamadas bravuras e volatas da garganta; ou transformada em afetada Dona, carregada dos arrebiques e ouropel de harmonias extravagantes e forçadas". Os diferentes momentos em que foram escritos, as opiniões convergem para um mesmo centro. Rousseau, na porta do classicismo, e José Bonifácio, já se encontrando com a decadência dos moldes clássicos, reclamam juntos, pelos cânones, que consideravam a música serva obediente da palavra. 
freqüentemente visitado por instrumentistas cujo repertório seria a música instrumental austro-alemã, como afirma Manuel Carlos de Brito (Brito, 1994, p. 107)

\section{Opiniões sobre a Música}

É com este subtítulo que Alberto Sousa abre os comentários sobre um texto, por ele selecionado, do discurso diante da Academia Real de Ciências de Lisboa, como já foi dito, em $1818^{52}$. Nesta pequena introdução, em linhas bastante gerais, objetiva-se apenas demonstrar que a preocupação do secretário da Real Academia de Ciências é um assunto que se confunde com a própria fundamentação da música. Vejamos, deste modo, como alguns temas abordados pelo pensador santista desenvolvem-se através da história.

Diz José Bonifácio:

[...] Para se avaliarem seus prodigiosos efeitos basta observar que a música militar, ainda em nossos dias, não só diminui no soldado as fadigas da campanha, mas em meio dos combates lhe inspira aquele ardor e hombridade que encara e despreza a mesma morte. E quanto maior seria seu efeito, se ao som dos instrumentos bélicos se unissem cantos guerreiros de algum novo Tirteo?...

Podemos associar este trecho a um debate presente desde a antigüidade clássica e tema recorrente nos textos dos seus principais filósofos. No seu projeto para a pólis, Platão usa a música como ideal educativo; na República, pensa em uma música cuja ação leve à virtude, chegando mesmo a classificar os modos de acordo com seus supostos ethos: aos guerreiros, os modos dório e frígio; para as festas, música em jônio e lídio (Platão, 1974, pp. 123-135). Transluz da mesma forma, o conhecimento, por parte do secretário brasileiro, do escrito de Aristóxeno:

[...] já os Gregos a experimentavam (a falta de tratados sobre música), pois apenas possuíram alguns Tratados sobre o gênero enharmonico, pela maior parte incompletos ou

52. Devemos comunicar que desconhecemos o original de Rodrigo Ferreira da Costa, Princípios de Música e Contraponto, sobre o qual foi feito a "opinião", esperamos, em um futuro breve, e contando com a fortuna de ele ainda existir, ter acesso a este trabalho. 
artificiais, como bem se colhe do que diz Aristoxenes em algumas passagens dos Livros $1^{\circ} \mathrm{e} 4^{\circ}$ dos seus Elementos harmônicos... ${ }^{\text {s3 }}$

Os patriarcas da Igreja Católica, como São Clemente, São Jerônimo, Santo Agostinho e Santo Ambrósio, revivem o valor educativo da música. Os modos, adaptados do sistema grego, obedeciam as circunstância da liturgia a ser cantada. Santo Agostinho se debate com o prazer das melodias, que se faria presente quando se respeitassem as regras do beni modulanti, em síntese a proporção (Fubini, 1988, p.74).

Outra preocupação de José Bonifácio é a relação música-texto. Assim como os modos, é este um tema constante no decorrer da história da música. Vemos como a luta visando a preponderâñicia de um elemento expressivo, ou seja, a música ou texto, caminha ao longo das muitas etapas da história da composição musical. É nas entranhas do canto gregoriano, que aparecem os tropos, mais tarde o organum, caminhando assim para a polifonia, onde a música desenvolvia-se como principal artífice da expressão, chegando até a bula papal de João XXII de 1322, que reage contra o excesso de notas. Afirma o Papa: "[...]a multidão de notas anula os simples e equilibrados raciocínios pelos quais, dentro do cantochão, se destingue uma nota das outras, correm e não se detêm jamais; embriagam os ouvidos e não se preocupam com os espíritos[...]" (apud Fubini, 1988, p. 116). A embriaguez dos ouvidos não seria um afluente passado das "bravuras e volatas da garganta" de José Bonifácio, ou ... "bobagens difíceis que o ouvido não pode suportar e a razão não pode justificar", de Rousseau?

Caminha a estruturação da forma musical afirmando-se sempre nos moldes da poesia. Com profundas modificações no contexto das discussões, novamente sofre a relação música-texto uma revolução no seu tratamento. Iniciada sob os auspícios do helenista Giovanni Bardi, a prática do recitar cantando encontra, a partir do prefácio do Livro V, "Il quinto libro de madrigali a 5 voci, col basso continuo per il clavicembalo, chitarrone

53. Aristóxeno é o filosofo que chama atenção para a importância da percepção, da prática musical, somando-se o interesse pelos aspectos intelectuais da música, ou seja, a teoria; diz que "a experiência musical tem, pois, seu fundamento no sentido" (Fubini, 1988, p. 74). Discordava de Platão no tocante ao ethos dos modos musicais, acreditando tratar-se de uma convenção histórica e que todos os modos poderiam ser usados, uma vez respeitados os limites sociais, até mesmo o "enharmônico", na época em desuso. 
od altro instrumento...", do ano de 1605 escrito por Cláudio Monteverdi as normas do novo estilo, chamado pelo compositor italiano de seconda prattica. A linha melódica, que se estrutura sem grandes saltos de intervalo, silabicamente (uma nota para cada sílaba ...recitando) é apoiada por um baixo contínuo, que apenas acompanha o canto-recitativo.

Voltando à época em questão, devemos considerar que José Bonifácio, já dentro do século XIX, mostra-se como um homem clássico discursando, assim como observa Emilia Viotti da Costa: "tendo vivido mais de trinta anos na Europa, identificara-se em vários aspectos com o pensamento ilustrado assimilando a visão crítica da burguesia européia" (Costa, 1986, p. 134). O velho mundo superava as divisões entre franceses e italianos e entrava na atmosfera subjetiva dos românticos alemães. Em 1818, Rossini já havia composto Tancredi (1813), La gazza ladra (1817) e no ano referido, Mosè in Egitto. Bellini tinha 17 anos era o último representante do bel canto, técnica que era o alvo das alfinetadas de José Bonifácio. Beethoven já tinha composto oito sinfonias e preparava-se para as últimas quatro sonatas. A harmonia mereceu então do nosso acadêmico, o qualificativo de "...afetada Dona, carregada de arrebiques e ouropel..." e possuidora de "ruidosas sutilezas...que pelo menos me parece assaz estéril em expressão e afetos..."

Acredita José Bonifácio no poder educativo da música, "amalga e ameiga os costumes, realça as sensações, espalha pelo povo prazeres puros e inocentes, e tem a mais desenganada influência no caráter moral e nobres da nossa alma...", postura orbitante a de Platão, como já foi visto. Poderia a música, ainda, para Andrada, apoiar-se reciprocamente no ensino das primeiras letras, e na ajuda da prosódia e pronunciação, assim como, através destes elementos, na solidificação dos seus fundamentos. Estamos diante da constatação do acadêmico das propriedades métricas da música. Nota-se o empenho do iluminista na utilização da "razão" musical, a utilização da proporção.

A simpatia declarada por músicos como Jommelli e Gluck evidencia o compromisso do literato José Bonifácio com a submissão da música ao texto. Podemos localizar, em teóricos clássicos, posturas próximas às do acadêmico. Esteban Arteaga, partidário da ópera italiana, que em 1783 lamentava o progresso da música instrumental que invadiu o melodrama deslocando o foco da poesia, dizia que "nos tempos áureos de Jommelli, Leo, Vinci e Pergolesi, a música se manteve dentro de seu próprios con- 
fins como comentário feito sobre as palavras..." (apud Fubini, 1988, p. 219). Vemos o conhecimento de causa das colocações do acadêmico, coerência que se faz presente na familiaridade com Gluck, - compositor que modifica alguns parâmetros convencionais da ópera, - sendo, o que mais nos interessa, a redescoberta do valor dramático perdido no bel canto italiano (Candé, 1994, pp. 590-591). O verbete do Grove Dictionary, dedicado a Jommelli, relaciona-o com Gluck, ressaltando ainda que o napolitano antecipa a descoberta do poder dramático do recitativo acompanhado, utilizado pelo mestre germânico ${ }^{54}$. Revela-se a agudeza dos gostos do futuro patriarca da independência.

A crítica aos excessos da harmonia tornam-se, então, coerentes com seu gosto musical, e acentuam mais uma vez o compromisso de José Bonifácio, monarquista, com o século que o formou.

\section{O Regresso em 1819}

Dois meses antes de regressar ao Brasil, em junho de 1819, no seu último discurso como secretário da Academia Real de Ciências, pode-se apurar o julgamento, de próprio punho, de seus conhecimentos musicais:

[...] mas se não tenho o gosto de ser iniciado em todo ${ }^{55}$ os mistérios e regras de tão nobre Arte, desvaneço-me de ser um de seus maiores apaixonados e amadores. Se a idade, e os estudos secos de minha profissão já tem afrouxado em muita parte a intensidade dos prazeres, que outrora me traziam as outras belas artes, suas irmãs, não sucede assim com a boa música vocal, devidamente acompanhada, que ainda produz em mim os mesmos maravilhosos efeitos, que causavam aos antigos Gregos, povo este o mais enérgico e sensível, que apresentam os anais da história (Silva, 1963, vol. 1, p. 460).

Quais seriam todos os mistérios e regras que pensava Bonifácio serem necessários saber, para satisfazerem seu conhecimento musical? Os padrões intelectuais do homem que se formou em direito, filosofia, mineralogia e que discursava com facilidade sobre história põem em questão as referências de suas dificuldades.

Ao desembarcar no Brasil em 1819, desconsola-o o que encontra: uma colônia atrasada e habitada por uma aristocracia e clero "...em muita parte ignorante e corrompida..." (Silva, 1998, p. 53). Chega a San-

54. Groves Dictionary of Music and Musicians, vol. IV, pp. 652-654. 
tos, porto do açúcar, ainda que evoluído em relação à vila que deixou anos atrás; sente-a vítima de "descuidos da governança ou desgovernança" (apud Sousa, 1957, p. 133), o abandono é a impressão que fica!

$\mathrm{O}$ amor pela música, porém, é o mesmo. Na visita relatada pelo barão de Eschwege, em 1820, ficou um relato, assim descrito por Octávio Tarquínio de Sousa:

Em sua casa havia alegres reuniões, como aquela que o alemão assistiu, de muita conversa, música e canto. D. Narcisa, mulher de José Bonifácio, com uma bela voz de contralto, cantou modinhas acompanhadas na guitarra; Gabriela, a segunda filha do casal, já moça feita, participou das conversas; e melhor de tudo, o próprio José Bonifácio, não obstante os seus cinqüenta e sete anos, dançou um lundu. E dançou magistralmente, segundo a opinião de Eschweg (Sousa, 1957, p. 134).

Mais do que a constatação da vida musical familiar, o destaque é o lundu do futuro Patriarca, dança de origem africana (Tinhorão, 1998), que causava a algumas décadas passadas, no menor dos casos, constrangimentos. Este é outro presente do repertório de surpresas que nos brinda José Bonifácio.

As danças de caráter popular não eram sufocadas na colônia. Poderiam sim, nas festas, ser separadas das atividades religiosas (Volpe, 1997, p. 37). Na celebração do nascimento da Princesa da Beira em 1794, a câmara de São Sebastião organiza uma festa onde não deixa de estar presente um "...baile de Congos feitos pelos homens pardos em praça da câmara"s6. Em outras épocas, este tipo de manifestação poderia ser motivo de escândalo, principalmente se fosse dançado por um padre. Francisco de Carrier, em 1714, sofre diversas acusações, que nos parecem fruto de uma disputa econômica entre o padre e a Câmara de vereadores, resultando em abertura de um processo em que constam faltas gravíssimas para a época, tais como assédio sexual à mulheres casadas e solteiras, negação de sacramento, convívio com gente desclassificada, e mais: "que em uma casa perante as pessoas familiares da dita casa em um dia de entrudo andara dançando descompostamente e que isto lhe contaram ... os mesmos familiares da mesma casa e não disse mais" ${ }^{\prime 57}$. Interessante é que o

55. Grifo nosso.

56. DAESP, Ofícios da Câmara de São Sebastião de 1721 a 1816, cx. 240.

57. ACMSP, PGA, crime-São Paulo, 1725. Apesar do processo ser de 1725 , o fato sucedeu-se na vila de Jundiaí em 1714. 
padre Carrier era músico formado na escola de Manuel Lopes de Siqueira (Duprat, 1995, p. 26); um músico afeto às manifestações profanas, em épocas tão remotas!

Foi este José Bonifácio que ouviu na matriz e nas ruas de Santos os músicos da época. Filhos de André de Moura, falecido em 1810, Francisco Manuel de Moura, Domingos José Martins e Lourenço Justiniano Rosa eram os profissionais que conhecemos. Juntavam-se a eles Leandro Bento de Barros e Manuel Joaquim da Trindade, este, pai de Luís Arlindo e Manuel Joaquim da Silva, que atravessariam o século XIX monopolizando a música santista. Poderia a percepção da insipiência se fazer novamente presente? Infelizmente, ainda nada podemos falar de positivo sobre a convivência de José Bonifácio com a música santista, porém. Seu espírito iluminista, reformador, nos dá alento para considerar a possibilidade de uma interferência, mesmo que para satisfazer os apaixonados ouvidos e saciando sua erudição.

Permanecendo pouco tempo em Santos, envolve-se na política brasileira e em 1821 assume o mandato, assim como o antigo mestre-decapela da Sé paulista, André da Silva Gomes, no governo provisório de São Paulo (Duprat, 1995, pp. 74-75). Todos sabemos dos sucessos subseqüentes da vida daquele que seria chamado de "Patriarca da Independência". $\mathrm{Na}$ corte brasileira encontrara-se com o padre José Maurício Nunes Garcia, suplicante por seus rendimentos e já envelhecido; Francisco Manuel da Silva, além de reencontrar Marcos Portugal, e uma atividade musical afetada com a volta de Dom João VI para Portugal (Mattos, 1997, p. 157).

Subia ao trono brasileiro o príncipe regente, futuro Dom Pedro, autor, entre outras obras, do hino da independência; músico e político, assim como José Bonifácio de Andrada e Silva.

\section{Bibliografia}

Amaral, Brenno Ferraz. José Bonifácio. São Paulo, Martins, 1968.

Andrade, Mário. Padre Jesuíno do Monte Carmelo. São Paulo, Livraria Martins, 1963. Assis, Machado de. Crônicas. São Paulo, W. M. Jackson Inc. editores, 1957. v. 1. Azevedo, Luiz Heitor Correia de. 150 Anos de Música no Brasil: 1800-1950. Rio de Janeiro, Livraria José Olympo, 1956. 
Blake, Augusto Victorino Alves Sacramento. Diccionario Bibliographico Brazileiro.

Rio de Janeiro, Kraus-Thompson, 1969. (Ed. fac-similada).

BrITo, Manuel Carlos de. "Breve Panorâmica da Ópera em Portugal no Século XVIII".

In: $1^{\circ}$ Encontro sobre Musicologia Histórica. Juiz de Fora: Universidade Federal de Juiz de Fora, 1994.

CAmargo, Monsenhor Paulo Florêncio da Silveira. A Igreja na História de São Paulo; 16761745, São Paulo, Cúria Metropolitana, 1953, vol. 3.

CANDÉ, Roland de. História Universal da Música. Trad. Eduardo Brandão. São Paulo, Martins Fontes, 1994.

Costa, Emilia Viotti da. José Bonifácio: Homem e Mito. In: Mota, Carlos Guilherme (org.). 1822: Dimensões. 2a ed. São Paulo, Perspectiva, 1986, pp. 103-159.

Davidson, Archbald \& Apel, Willi. Historical Anthology of Music. 7 ed. Cambridge, Havard University Press, 1968.

Dinız, Jaime C. Mestres de Capela da Misericórdia da Bahia 1647-1810. Salvador:

Centro Editorial e Didático da UFBa, 1993.

Duprat, Régis. Antecipando a história da música no Brasil. Revista do Patrimônio Histórico e Artístico Nacional. São Paulo, 20: pp. 25-28, 1984. Garimpo Musical. São Paulo, Novas Metas, 1985. Música na Sé de São Paulo Colonial. São Paulo, Paulus, 1995.

GRoves Dictionary of Music and Musicians. Londres, Macmillian \& CO 1td, 1954.

FalCão, Edgar Cerqueira (org.). Obras Científicas, Políticas e Sociais de José Bonifácio de Andrada e Silva. Santos, s/e, 1963.

Fubini, Enrico. La Estética Musical desde la Antigüedad hasta el Siglo XX. Madrid, Alianza Editorial, 1988.

Lange, Francisco Curt. A Organização Musical durante o Período Colonial Brasileiro. Coimbra, V Colóquio Internacional de Estudos Luso-brasileiro, 1966.

"Pesquisa Esporádica de Musicologia no Rio de Janeiro". Revista do Instituto de Estudos Brasileiros. São Paulo, Universidade de São Paulo, 4, pp. 99-142, 1968.

Madre de Deus, Gaspar. Memórias para a História da Capitania de São Vicente. São Paulo, Ed. da Universidade de São Paulo, 1975.

Martins, José Eduardo. Encontros sob Música. Belém do Pará, Edições CEJUP, 1990. Matros, Cleofe Person de. José Maurício Nunes Garcia-Biografia. Rio de Janeiro, Fundação Biblioteca Nacional, Departamento Nacional do Livro, 1996.

Moraes, Rubens Borba de. Bibliografia Brasileira do Período Colonial. São Paulo, Instituto de Estudos Brasileiros da Universidade de São Paulo, 1969.

Petrone, Pasquale. "Povoamento e Caminhos nos Séculos XVI e XVII" \& "Povoamento e Caminhos no Século XVII e Primeira Metade do Século XIX”. In: AzEvedo, Aroldo (org.). A Baixada Santista. Aspectos Geográficos. São Paulo, Editora da Universidade de São Paulo, 1965.

Platão. La República. Estudios y análisi crítico de M. Cristina Vergara. Santiago de Chile, Ediciones Delfín, 1974. 
Pompeo, A. Os Paulistas e a Igreja. São Paulo, Empreza Graphica da "Revista dos Tribunaes", 1929, v. 1.

SAnTos, Francisco Martins dos. Historia de Santos. Santos, Fernando Martins Lichti editor, vol. 1, 1986.

SANToS, padre Luiz Gonçalves dos. Memórias para Servir a História do Reino do Brasil. Lisboa, Impressão Régia, 1825, vd. 1.

SANTos, Maria Luiza de Queiroz Amancio. Origem e Evolução da Música em Portugal e sua Influência no Brasil. Rio de Janeiro. Comissão Brasileira do Centenário de Portugal no Brasil, 1942.

Silva, Ana Rosa Cloclet da. Construção da Nação e Escravidão no Pensamento de José Bonifácio: 1783-1823. Campinas, Editora da Unicamp. 1999.

Silva, José Bonifácio de Andrada e. Projetos para o Brasil. Míriam Dolhnikoff (org.). São Paulo, Companhia das Letras, 1998.

Silva Leme, Luiz Gonzaga da. Genealogia Paulistana. São Paulo, Duprat \& Comp, 1905.

Sousa, Octávio Tarquínio. História dos Fundadores do Império do Brasil. $2^{\mathrm{a}}$ edição. Rio de Janeiro, José Olympo editora, 1957, vol. 1.

SouzA, Alberto. Os Andradas. São Paulo, Typographia Piratininga. 1922. 3 vols.

Souza Junior, João Cardoso de Menezes e. A Harpa Gemedora. São Paulo, Typografia de Silva Sobral, 1847.

Tinhorão, José Ramos. História Social da Música Popular Brasileira. São Paulo, Editora 34, 1998.

Trindade, Jaelson. "Música Colonial Paulista: O Grupo de Mogi das Cruzes". Revista do Patrimônio Histórico e Artístico Nacional. São Paulo, 20, pp. 15-24, 1984.

Volpe, Maria Alice. "Irmandades e Ritual em Minas Gerais durante o Período Colonial O Triunfo Eucarístico de 1733. Revista Música. São Paulo, Departamento de Música, Universidade de São Paulo, 8 (1/2): 5-55, maio/novembro, 1997.

\section{Abreviaturas e Siglas de Arquivos e Coleções Citadas}

ACMSP - Arquivo da Cúria Metropolitana de São Paulo;

AHUL, SP, cat. - Arquivo Histórico Ultramarino de Lisboa, São Paulo, catalogados (cf. Catálogo da RIHGB);

AISCMS - Arquivo da Irmandade da Santa Casa de Misericórdia de Santos;

AMP - Arquivo do Museu Paulista;

BN - Biblioteca Nacional do Rio de Janeiro;

DAESP - Divisão de Arquivo do Estado de São Paulo;

DI - Documentos Interessantes para a História e Costumes de São Paulo, publicados pelo DAESP;

FAMS - Fundação Arquivo e Memória de Santos;

PGA - Processos gerais antigos do ACMSP; 
152 Revista Música, São Paulo, v. 9 e 10, pp. 121-152, 1998-1999

PHGM - Processos históricos de genere et moribus do ACMSP;

RIHGB - Revista do Instituto Histórico e Geográfico Brasileiro;

RIHGSP - Revista do Instituto Histórico e Geográfico de São Paulo. 